\title{
Late Paleoindian-Early Archaic Dart Points from the Wolfshead Site (41SA117) in the Angelina River Basin in East Texas
}

Timothy K. Perttula

Heritage Research Center, Stephen F. Austin State University

Mark Walters

Heritage Research Center, Stephen F. Austin State University

Follow this and additional works at: https://scholarworks.sfasu.edu/ita

Part of the American Material Culture Commons, Archaeological Anthropology Commons, Environmental Studies Commons, Other American Studies Commons, Other Arts and Humanities Commons, Other History of Art, Architecture, and Archaeology Commons, and the United States History Commons

Tell us how this article helped you.

This Article is brought to you for free and open access by the Center for Regional Heritage Research at SFA ScholarWorks. It has been accepted for inclusion in Index of Texas Archaeology: Open Access Gray Literature from the Lone Star State by an authorized editor of SFA ScholarWorks. For more information, please contact cdsscholarworks@sfasu.edu. 


\section{Late Paleoindian-Early Archaic Dart Points from the Wolfshead Site (41SA117) in the Angelina River Basin in East Texas \\ Creative Commons License \\ (c) (1) (8)}

This work is licensed under a Creative Commons Attribution-NonCommercial 4.0 International License 


\title{
Late Paleoindian-Early Archaic Dart Points from the Wolfshead Site (41SA117) in the Angelina River Basin in East Texas
}

\author{
Timothy K. Perttula and Mark Walters
}

\section{INTRODUCTION}

The Wolfshead site (41SA117) was excavated by the Texas Archeological Salvage Project at The University of Texas in 1960 prior to the inundation of the site by the waters of Lake Sam Rayburn in the Angelina River basin in East Texas (Duffield 1963). The site was located on a sandy terrace and covered ca. 1 acre in size; the sandy deposits were a maximum of ca. $60 \mathrm{~cm}$ in thickness below an historic plow zone (Duffield 1963:Figure 2).

The excavations in the northern and southern parts of the site (see Duffield 1963:Figure 3) indicated that the Wolfshead site had an extensive Late Paleoindian-Early Archaic San Patrice culture occupation estimated to date between ca. 10,500-9800 years B.P. based on the radiocarbon dating of archaeological deposits with San Patrice points in sites in the Woodland and Southern Plains in south central North America (see Jennings 2008a, 2008b). San Patrice components cluster "in the eastern half of Texas, where prairies and woodlands would have predominated" (Bousman et al. 2004:74 and Figure 2.46h).

The component at the Wolfshead site is marked by a number of distinctive dart points, as discussed in the next section, as well as scraping tools (see Duffield 1963:Figure 12), and Albany scrapers (Duffield 1963:Figure 13h). The Albany scrapers were made on local petrified wood, while the unifacial side and end scrapers were manufactured on both petrified wood and pebble cherts.

\section{Late Paleoindian-Early Archaic Dart Points from the Wolfshead Site}

Late Paleoindian to Early Archaic period dart points are common in the archaeological deposits at the Wolfshead site with 41 points and preforms in the collections at the Texas Archeological Research Laboratory at the University of Texas at Austin (Table 1). Only two types are identified in the assemblage: Pelican (see Anderson and Smith 2003:277-278) and San Patrice (n=32); about 19.5 percent of the dart points are side-notched $(\mathrm{n}=8)$, and these are probably another variety (var. Dixon) of San Patrice (Anderson and Smith 2003:280 and Figure 5.10b-d).

Table 1. Dart points from the Wolfshead Site (41SA117).

\begin{tabular}{llllllll}
\hline Type & \multicolumn{9}{l}{ Raw Material } & & \\
& rc & brc & g/dgc & wc & J & PW & QTZ \\
\hline Pelican & - & - & 1 & - & - & - & - \\
San Patrice, var. Hope & - & - & - & - & 1 & 5 & 3 \\
San Patrice, var. St. Johns & 2 & 5 & 2 & - & - & 11 & - \\
San Patrice, preform & - & 1 & - & 1 & 1 & - & - \\
Side-notched & - & 1 & - & 1 & - & 5 & 1 \\
\hline Totals & 2 & 7 & 3 & 2 & 2 & 21 & 4 \\
\hline
\end{tabular}

$\mathrm{rc}=$ red chert; brc=brown chert; $\mathrm{g} / \mathrm{dgc}=$ gray to dark gray chert; $\mathrm{wc}=$ white chert; $\mathrm{J}=$ jasper; $\mathrm{PW}=$ petrified wood; $\mathrm{QTZ}=\mathrm{quartzite}$ 


\section{Pelican}

The one classified Pelican point (Figure 1a) has a straight stem with grinding on the base and stem (see Duffield 1963:97); it was made on a non-local and translucent gray chert. Duffield suggested the point was a Scottsbluff point, but Webb (2000) considers the Pelican point in general to be a preform to a San Patrice, var. Hope point (Morehead and Lafitte 2014:19).

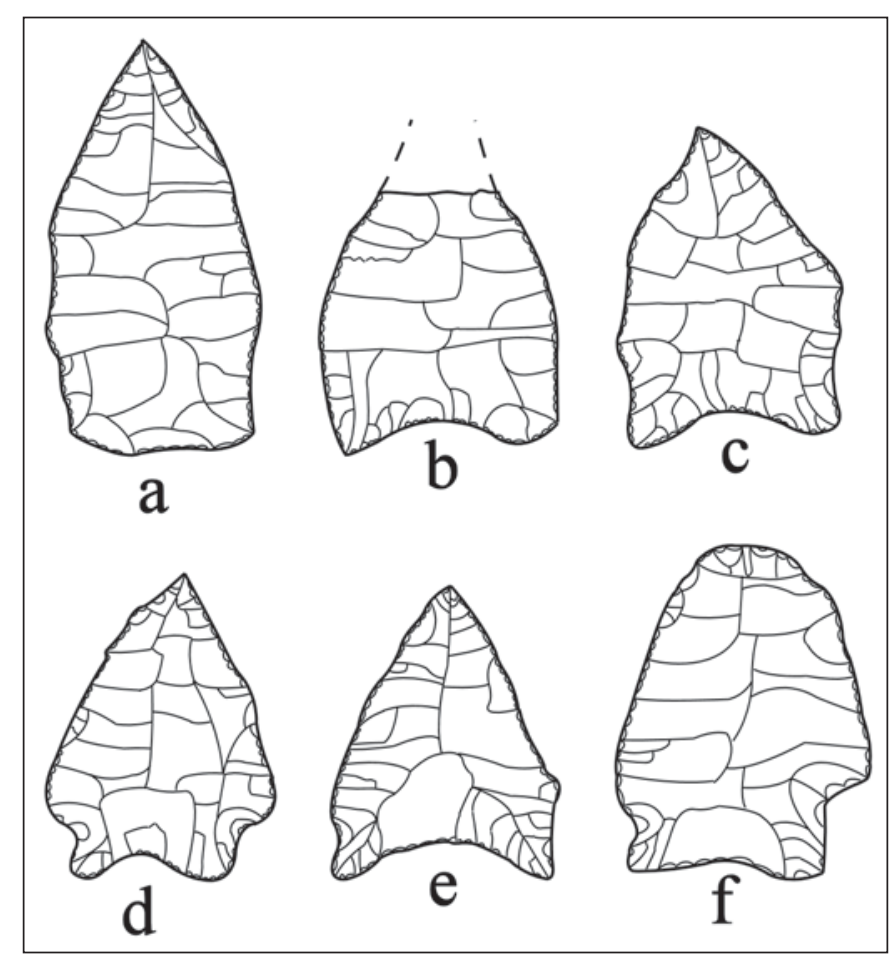

Figure 1. Pelican and San Patrice, var. Hope dart points from the Wolfshead site: a, Pelican; b-f, San Patrice, var. Hope.

\section{San Patrice, var. Hope}

According to Duffield (1963:91-92), the var. Hope San Patrice dart points have "slightly concave sides which define the stem. All the bases have been thinned and the short blades have slightly concave to slightly convex edges." One var. Hope point from the Wolfshead site is made from Red River jasper and the others are manufactured on local petrified wood or quartzite (see Table 1 and Figure $1 \mathrm{~b}-\mathrm{f}$ ).

\section{San Patrice, var. St. Johns}

This is the most common variety of San Patrice point at the Wolfshead site, with 20 examples (Figure 2a-t). Duffield (1963:91) defined this variety as follows:

The st. johns group has small, but unusually prominent, oblique side notches, situated immediately above the base, which define the shoulders and stem...[t]he blades are short, subtriangular in shape, and have edges which vary from concave to convex.

The var. St. Johns points also have thinned bases with short fluting flakes. The blades are commonly resharpened, and several (Figure $2 \mathrm{f}-\mathrm{g}$, i) have serrated or beveled (Figure $2 \mathrm{~h}$ ) blades. These points were made on local brown and red chert and petrified wood (see Table 1), with 10 percent made from non-local gray (Figure 2c) or dark gray chert (Figure 2d). 


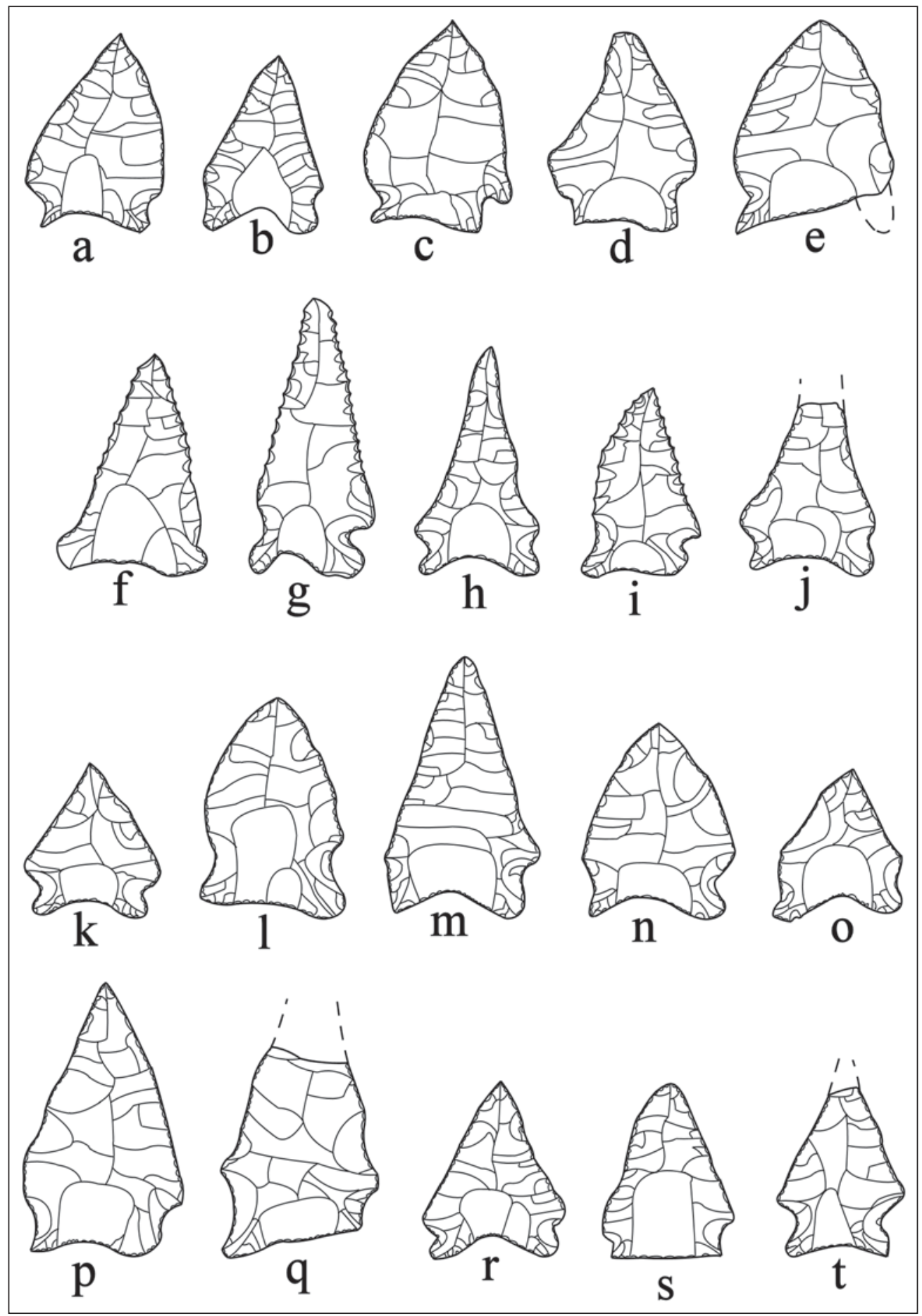

Figure 2. San Patrice, var. St. Johns dart points from the Wolfshead site. 


\section{San Patrice preforms}

There are three San Patrice point preforms in the Wolfshead site chipped stone tool assemblage (Figure 3a-b). The larger preform, with basal thinning, is made from a fine-grained tan quartzite (Figure 3a), another is made from a brown Red River jasper (Figure 3b), and the third preform — broken laterally—was made from a non-local white chert.

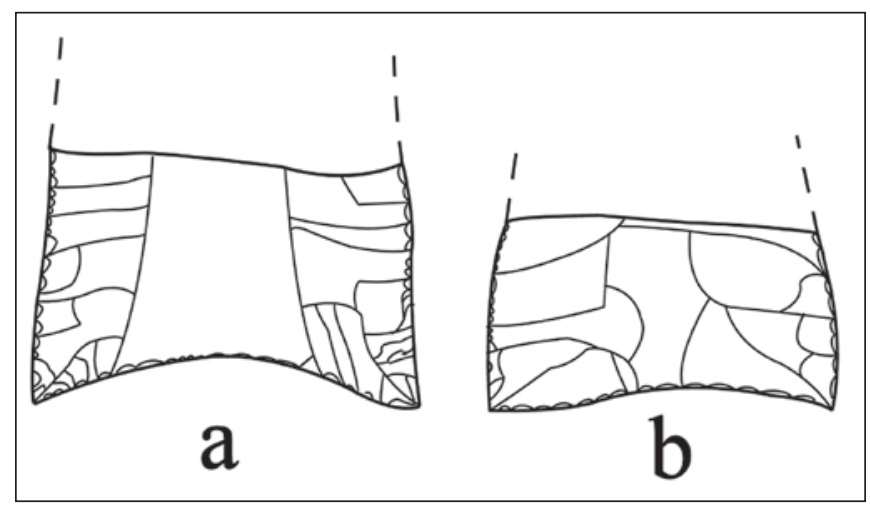

Figure 3. San Patrice point preforms.

\section{Side-notched dart points}

There are eight side-notched dart points in the assemblage from the Wolfshead site (Figure 4a-h); most are made of a local petrified wood. Six have broad side notches with either flat or concave bases, and several are ground on the base (Figure $4 \mathrm{e}-\mathrm{f}$ ). Two others (Figure $4 \mathrm{~g}-\mathrm{h}$ ) may be San Patrice, var. Dixon points. These points may represent a slightly later use of the site, from ca. 10,000-9800 years B.P., and be part of a transitional Late Paleoindian-Early Archaic occupation (Rees 2010:56). Pevny (2014:Figure 5) illustrates similar side-notched dart points from the Twin Bird Island site (16CD118) in Northwest Louisiana, and Pevny (2014:121) considers them to be of Early Archaic period age.

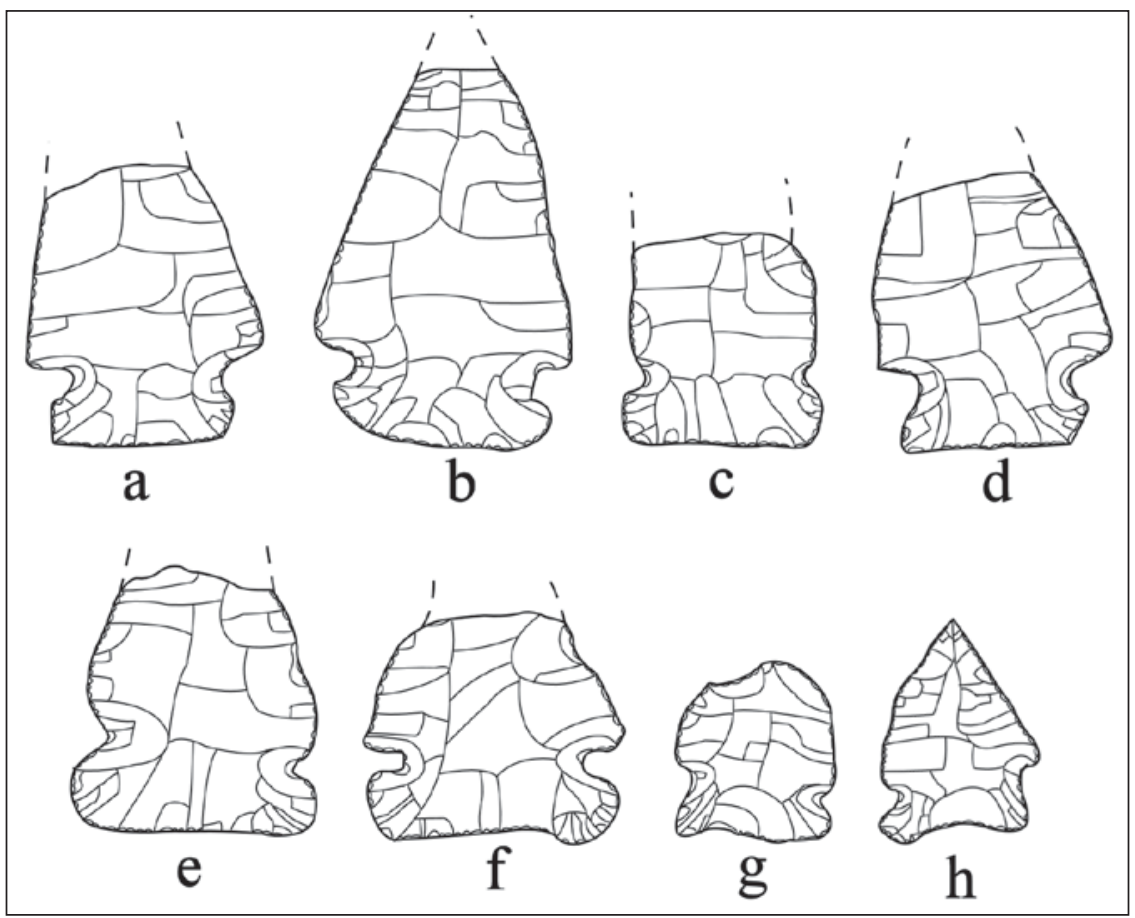

Figure 4. Side-notched dart points from the Wolfshead site (41SA117). 


\section{SUMMARY AND CONCLUSIONS}

The Wolfshead site (41SA117) in the Angelina River basin in East Texas was excavated in 1960 prior to the construction of Lake Sam Rayburn. The excavations disclosed that the site had important and substantial Late Paleoindian-Early Archaic period deposits marked by a number of San Patrice dart points and other chipped stone tools (including unifacial scrapers and Albany scrapers); the occupation here likely dates from ca. 10,500-9800 years B.P. In addition to several San Patrice point preforms and one Pelican point, the dart point assemblage at the Wolfshead site includes San Patrice, var. Hope $(\mathrm{n}=9)$ and var. St. Johns $(\mathrm{n}=20)$ points as well as eight distinctive side-notched darts that may also comprise part of the same component, or a slightly later Early Archaic use of the site. There were no preserved organic remains in the archaeological deposits, and the precise age of the San Patrice component at the Wolfshead site remains unknown.

About 83 percent of the Late Paleoindian-Early Archaic dart points from the Wolfshead site are made from lithic raw materials locally available in the Angelina River basin in East Texas, including red chert, brown chert, petrified wood, and quartzite (see Table 1). The use of petrified wood is most common, as petrified wood San Patrice, var. Hope and St. Johns points comprise 50 percent of the dart point sample, and 62.5 percent of the side-notched points are made from petrified wood. San Patrice projectile points and associated tools are typically manufactured on local raw materials, at least in sites then situated in the woodlands (see Jennings 2008a, 2008b). In plains San Patrice sites, about 21 percent of the San Patrice points are made from exotic raw material sources compared to only 6 percent of the San Patrice points from woodland contexts (Jennings 2008a:Table 7); the use of non-local lithic raw materials for dart point manufacture in the Wolfshead assemblage is more like the pattern of raw material use documented in plains San Patrice sites.

\section{ACKNOWLEDGMENTS}

We appreciate the fact that Lance Trask prepared the figures in this article.

\section{REFERENCES CITED}

Anderson, D. G. and S. D. Smith

2003 Archaeology, History, and Predictive Modeling: Research at Fort Polk 1972-2002. The University of Alabama Press, Tuscaloosa.

Bousman, C. B., B. W. Baker, and A. C. Kerr

2004 Paleoindian Archeology in Texas. In The Prehistory of Texas, edited by T. K. Perttula, pp. 15-97. Texas A\&M University Press, College Station.

Duffield, L. F.

1963 The Wolfshead Site: An Archaic-Neo-American Site in San Augustine County, Texas. Bulletin of the Texas Archeological Society 34:83-141.

Jennings, T. A.

2008a San Patrice Technology and Mobility across the Plains-Woodland Border. Memoir 12, Oklahoma Anthropological Society, and R. E. Bell Monographs in Anthropology No. 5, Sam Noble Oklahoma Museum of Natural History, University of Oklahoma, Norman.

2008b San Patrice: An Example of Late Paleoindian Adaptive Versatility in South-Central North America. American Antiquity 73(3):539-559.

Morehead, J. and B. Lafitte

2012 The San Patrice Culture at Fort Polk, Louisiana: The Anacoco Phase and the Distribution of Related Paleoindian and Early Archaic Cultural Components. Louisiana Archaeology 37:9-80. 
Pevny, C. D.

2014 Twin Bird Islands (16CD118): A Late Paleoindian-Early Archaic Site in Caddo Parish, Louisiana. Louisiana Archaeology 37:108-141.

Rees, M. A.

2010 Paleoindian and Early Archaic. In Archaeology of Louisiana, edited by M. A. Rees, pp. 34-62. Louisiana State University Press, Baton Rouge.

Webb, C. H.

2000 Stone Points and Tools of Northwestern Louisiana. 2nd Edition. Special Publication No. 1. Louisiana Archaeological Society, Baton Rouge. 